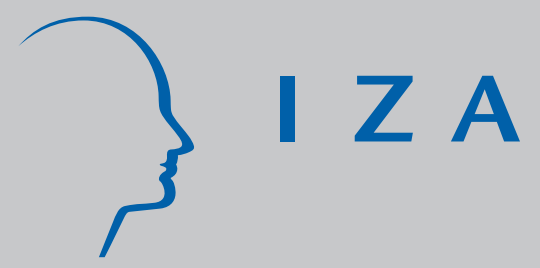

IZA DP No. 3

Temporary Migrants From Egypt:

How Long Do They Stay Abroad?

Ira N. Gang

Thomas K. Bauer

April 1998 


\title{
TEMPORARY MIGRANTS FROM EGYPT: HOW LONG DO THEY STAY ABROAD?
}

\author{
Thomas K. Bauer \\ Ira N. Gang
}

\author{
Discussion Paper No. 3 \\ April 1998
}

IZA

P.O. Box 7240

D-53072 Bonn

Germany

Tel: +49-228-3894-201

Fax: +49-228-3894-210

Email: iza@iza.org

This Discussion Paper is issued within the framework of IZA's research area Mobility and Flexibility of Labor Markets. Any opinions expressed here are those of the author(s) and not those of the institute. Research disseminated by IZA may include views on policy, but the institute itself takes no institutional policy positions.

The Institute for the Study of Labor (IZA) in Bonn is a local and virtual international research center and a place of communication between science, politics and business. IZA is an independent, nonprofit limited liability company (Gesellschaft mit beschränkter Haftung) supported by the Deutsche Post AG. The center is associated with the University of Bonn and offers a stimulating research environment through its research networks, research support, and visitors and doctoral programs. IZA engages in (i) original and internationally competitive research in all fields of labor economics, (ii) development of policy concepts, and (iii) dissemination of research results and concepts to the interested public. The current research program deals with (1) mobility and flexibility of labor markets, (2) internationalization of labor markets and European integration, (3) the welfare state and labor markets, (4) labor markets in transition, (5) the future of work, and (6) general labor economics.

IZA Discussion Papers often represent preliminary work and are circulated to encourage discussion. Citation of such a paper should account for its provisional character. 
IZA Discussion Paper No. 3

April 1998

\section{ABSTRACT}

\section{Temporary Migrants from Egypt: How Long Do They Stay Abroad?*}

This paper analyzes the determinants and timing of return migration. Special attention is given to the role of social and informational migration networks. A simple theoretical model of temporary migration demonstrates that the effect of migration networks on optimal migration duration is ambiguous. Using a sample of return migrants from six different villages in Egypt we investigate the determinants of migration duration using a flexible parametric proportional hazard model for discrete duration data. Controlling for human capital and demographic characteristics of the migrants and economic indicators for the host country, the estimation results show that informational networks have a statistically significant negative effect on migration duration.

JEL Classifications: J61

Keywords: return migrants, duration of migration

Ira N. Gang

Economics Department

Rutgers University

New Brunswick NJ 08901-1248 USA

Tel.: +1 732 932-7405

email: gang@economics.rutgers.edu

* The authors thank Gail Alterman, Debajyoti Chakrabarty, Charles Romeo and Myeong-Su Yun for helpful comments on this paper. This paper was written while Thomas Bauer was visiting Rutgers University under the auspices of a Feodor Lynen Fellowship of the Alexander von Humboldt Foundation. 


\section{Introduction}

Egypt experienced large scale international emigration to oil rich countries in the Middle East in the 1970s and 1980s. In 1985 between 2.5 and 3.5 million Egyptians worked abroad. This was approximately $10 \%$ of the total labor force (Sell, 1988). These large emigration flows had dramatic effects on specific Egyptian labor markets. For example, Richards (1994) calculates that roughly two-thirds of the reduction in the agricultural labor force in $1983 \mathrm{can}$ be explained by emigration. Following this large-scale emigration in the 1970 s the wage rate in the agricultural sector increased by $235 \%$, and in the construction sector by $500 \%$ (Aly and Shields, 1996). Egyptian migration is largely a temporary phenomenon. Most migrants return to Egypt after spending some time in a host country. According to a 1987 survey, $59 \%$ of rural Egyptian migrants return within two years and 78\% within three years (Richards, 1994).

We analyze the determinants and timing of return migration. Both the theoretical and the empirical literature on temporary migration treat return migration as part of life-cycle planning. While the models differ in their nuances, return migration is an optimal decisionmaking phenomenon related to the savings behavior of immigrants, their investment in human capital acquisition in the host country, and the relative wage differences between the host and sending country (examples include Dustmann (1997) and Stark, Helmenstein and Yegorov (1997)). The length of time abroad is related to the acquisition of these assets. The link, however, between the actual length of time abroad and life cycle considerations is tenuous and subject to a number of exogenous shocks.

We emphasize the role of social and informational networks as determinants of migration duration. Ties of kinship, friendship, and village, link migrants, former migrants, and nonmigrants in the home and host country. In an uncertain environment, migration networks provide information about the labor market in the host country and thus may increase the expected wage and decrease uncertainty by enabling the migrant to obtain better paid and more stable jobs. Based on the previous work of Dustmann (1997) we develop a simple model for analyzing migration duration in a situation of uncertainty about the wage rate in the host country. The model shows the two main effects of networks, an increase in the expected wage and a decrease in the degree of uncertainty, have ambiguous effects on optimal migration duration.

The empirical part of this paper uses a sample of individuals from six geographically and 
ethnically diverse villages in Egypt, which contains detailed information on their migration histories. The empirical analysis faces several methodological problems which we address in the econometric framework. Our measure of length of a stay is the number of years abroad. Rather than assume that this represents a continuous variable, we think of the years abroad as corresponding to a conceptually continuous index. What we observe, i.e., the number of years abroad, corresponds to a specific range of the index. Thus, we estimate a flexible parametric proportional hazard model for discrete duration data as proposed by Han and Hausman (1990). In essence, this model is an ordered logit model, where the threshold values are interpreted as the logs of the baseline hazard.

The next section develops our theoretical model. Section III describes our data and the representativeness of the sample we employ. In Section IV we discuss our econometric framework. The estimation results are presented in Section V; Section VI concludes.

\section{Theoretical Framework}

The theoretical literature on temporary migration treats return migration as part of life-cycle planning where return migration is an optimal decision-making phenomenon. In most of the existing models return migration of individuals is achieved by assuming that the marginal utility of consumption is higher in the home country than in the receiving country (see Djajic and Milbourne, 1988; Dustmann, 1997; Hill, 1987; and Stark, Helmenstein and Yegorov, 1997). Alternative motives for return migration are developed by Dustmann (1995) who assumes that relatively high returns to human capital investments made in the receiving country are responsible for return migration, and by Stark (1995) who models return migration as the result of employer learning about the skills of temporary migrants. Our approach is to focus on the role of migration networks, their influence on the uncertainty about the wage rate in the host country, and thus on the optimal duration of migration. The theoretical model we develop builds on the framework provided by Dustmann (1997) who analyzes the simultaneous determination of consumption and re-migration in a stochastic environment. Compared to Dustmann (1997) our model is highly simplified and approaches the analysis of uncertainty on migration duration in a different way.

Let the lifetime horizon of the migrant be equal to $\mathrm{T}=1$ and assume that the individual is productive over his entire life cycle. The migrant has to choose the time the wants to stay in the host country, leaving time $(1-t)$ for the home country. The migrant's objective is to 
maximize lifetime utility from consumption. Assume that the lifetime utility function is additively separable in consumption in the host and home country, and that the respective subutility functions are increasing in consumption, strictly concave and continuously differentiable. We further assume that the rate of time preference and the interest rate are both equal to zero, and that the host and home countries are small enough to set their respective price levels for goods equal to one. Given these assumptions, the lifetime utility function of the migrant can be expressed as (see Dustmann, 1997, and Stark, Helmenstein and Yegorov, 1997)

$$
\mathrm{U}\left(\mathrm{c}_{\mathrm{H}}, \mathrm{c}_{\mathrm{I}}, \mathrm{t}\right)=(1-\mathrm{t}) \mathrm{u}_{\mathrm{H}}\left(\mathrm{c}_{\mathrm{H}}\right)+\mathrm{t} \mathrm{u}_{\mathrm{I}}\left(\mathrm{c}_{\mathrm{I}}\right)
$$

where $\mathrm{u}_{\mathrm{H}}$ and $\mathrm{u}_{\mathrm{I}}$ are the sub-utility functions in the home and the immigration country; $\mathrm{c}_{\mathrm{H}}$ and $\mathrm{c}_{\mathrm{I}}$ are the respective constant flows of consumption. Following previous models in the related literature ${ }^{1}$, we assume that the individual has a higher preference for consumption at home, i.e., for an equal consumption flow $\mathrm{k}$ in both countries $\mathrm{u}_{\mathrm{H}}(\mathrm{k})>\mathrm{u}_{\mathrm{I}}(\mathrm{k}), \mathrm{u}_{\mathrm{H}}^{\prime}(\mathrm{k})>\mathrm{u}_{\mathrm{I}}^{\prime}(\mathrm{k})$, and $\mathrm{u}_{\mathrm{H}}(0)=\mathrm{u}_{\mathrm{I}}(0)=0$. The wage rates in both countries are given by $\mathrm{w}_{\mathrm{H}}$ and $\mathrm{w}_{\mathrm{I}}$, respectively. For fixed migration costs $\gamma$, the lifetime budget constraint of the migrants can be written as

$$
(1-t) c_{H}+t c_{I}=(1-t) w_{H}+t w_{I}-\gamma
$$

In what follows we consider the case where $\mathrm{w}_{\mathrm{I}}$ is a random variable, with $\mathrm{f}\left(\mathrm{w}_{\mathrm{I}}\right)$ being the migrants' subjective probability density on $\mathrm{w}_{\mathrm{I}}$. To describe the migrants' attitude toward risk we adopt the Arrow-Pratt hypothesis of decreasing absolute risk aversion by specifying a coefficient of absolute risk aversion, $\mathrm{R}=-\mathrm{u}_{\mathrm{H}}^{\prime \prime} / \mathrm{u}_{\mathrm{H}}^{\prime}>0$. We assume this term to be invariant to the migrants' time allocation and decreasing in consumption, i.e., $\partial \mathrm{R} / \partial \mathrm{t}=0$, and $\partial \mathrm{R} / \partial \mathrm{c}_{\mathrm{i}}<0$, for $\mathrm{i}=\mathrm{H}, \mathrm{I}$. Uncertainty about the wage rate in the host country has several motivations. First, unexpected macroeconomic and political changes in the labor market affect the wage rate in the host country. Second, uncertainty about $\mathrm{w}_{\mathrm{I}}$ evolves according to imperfect information regarding the labor market in the host country.

1 See Djajic and Milbourne (1988), Dustmann (1997), Hill (1987), and Stark, Helmenstein and Yegorov (1997). 
Migration networks are usually interpreted as interpersonal connections that link migrants, former migrants and non-migrants in the home and the host country by ties of kinship and friendship. ${ }^{2}$ They offer important data that work to mitigate imperfect information about the labor market in the host country. These personal connections provide potential migrants with information about the labor market in the host country. Therefore, a larger network may increase the expected wage in the host country, $\mathrm{E}\left[\mathrm{w}_{\mathrm{I}}\right]$, and decrease the variability of $\mathrm{w}_{\mathrm{I}}$, since migrants who can rely on a network have a higher probability of finding better paid and more stable jobs. ${ }^{3}$

To simplify the following analysis, we assume that the migrant does not consume in the host country, $c_{I}=0$, that there are no migration costs, $\gamma=0$, and that the wage in the home country equals zero, $\mathrm{w}_{\mathrm{H}}=0$. Given these assumptions, the optimization problem of the migrant reduces to

$$
\begin{gathered}
\max _{\mathrm{t}} \int_{0}^{\infty} \mathrm{U}\left(\mathrm{c}_{\mathrm{H}}, \mathrm{t}\right) \mathrm{f}\left(\mathrm{w}_{\mathrm{I}}\right) \mathrm{d} \mathrm{w}_{\mathrm{I}}, \\
\text { s.t. } \quad \mathrm{c}_{\mathrm{H}}=\frac{\mathrm{t}}{1-\mathrm{t}} \mathrm{w}_{\mathrm{I}} .
\end{gathered}
$$

In particular, we are interested in the migration duration of those who emigrate and return.

Hence we assume that spending some time in the host country is optimal for the migrant, ${ }^{4}$ i.e., $0<\mathrm{t}<1$. The first and second order conditions for a relative maximum are

$$
\mathrm{E}\left[\mathrm{w}_{\mathrm{I}} \mathrm{u}_{\mathrm{H}}^{\prime}\right]-(1-\mathrm{t}) \mathrm{E}\left[\mathrm{u}_{\mathrm{H}}\right]=0,
$$

and

2 See Bauer (1995), Boyd (1989), Massey (1990), and Massey et.al. (1993). Empirical studies of the relevance of social networks are provided by Banerjee (1983) and Bauer and Zimmermann (1997).

3 Social networks also may decrease the monetary and psychological costs of migration (see Bauer, 1995). In what follows we consider only the wage effects.

4 See Stark, Helmenstein, and Yegorov (1997) for a discussion of the situations where $\mathrm{t}=0$ or $\mathrm{t}=1$. 


$$
\mathrm{Z} \equiv \frac{\partial^{2} \mathrm{U}}{\partial \mathrm{t}^{2}}=\frac{\mathrm{E}\left[\mathrm{w}_{\mathrm{I}}^{2} \mathrm{u}_{\mathrm{H}}^{\prime \prime}\right]}{(1-\mathrm{t})^{3}}<0
$$

with $\mathrm{u}_{\mathrm{H}}^{\prime}=\partial \mathrm{u}_{\mathrm{H}} / \partial \mathrm{c}_{\mathrm{H}}$, and $\mathrm{u}_{\mathrm{H}}^{\prime \prime}=\partial^{2} \mathrm{u}_{\mathrm{H}} / \partial \mathrm{c}_{\mathrm{H}}^{2}$, respectively. Equation (4) shows that the choice of the optimal time in the host country by the migrant is such that the expected marginal gain of staying one time unit longer abroad equals the expected marginal loss in overall utility of staying one time unit longer abroad (see Dustmann, 1997, and Stark, Helmenstein, and Yegorov, 1997). ${ }^{5}$ Solving equation (4) for t, the optimal time of staying abroad is given by

$$
\mathrm{t}^{*}=1-\frac{\mathrm{E}\left[\mathrm{w}_{\mathrm{I}} \mathrm{u}_{\mathrm{H}}^{\prime}\right]}{\mathrm{E}\left[\mathrm{u}_{\mathrm{H}}\right]} \text {. }
$$

We now want to study the effect of uncertainty about the wage rate in the host country, $\mathrm{w}_{\mathrm{I}}$. Consider first the effect of a shift in the expected wage rate in the host country on the time allocation of the migrant when all other moments around the mean of $\mathrm{w}_{\mathrm{I}}$ are fixed. ${ }^{6}$ Replacing $\mathrm{w}_{\mathrm{I}}$ in equation (4) with $\alpha_{1} \mathrm{w}_{\mathrm{I}}+\beta_{1}$, where $\beta_{1}$ is the shift parameter and $\alpha_{1}=1$, differentiating with respect to $\beta_{\mathrm{I}}$, and evaluating the result at $\beta_{1}=0$ leads to

$$
\frac{\mathrm{dt}^{*}}{\mathrm{~d} \beta_{1}}=-\frac{\mathrm{E}\left[\mathrm{u}_{\mathrm{H}}^{\prime}\right]}{\mathrm{Z}}-\frac{\mathrm{t}}{(1-\mathrm{t})^{2}} \frac{\mathrm{E}\left[\mathrm{w}_{\mathrm{I}} \mathrm{u}_{\mathrm{H}}^{\prime \prime}\right]}{\mathrm{Z}} .
$$

The first term on the right-hand side of equation (7) is the substitution effect of a change in the expected wage-rate of the host country and is obviously positive. An increase in the expected wage-rate of the host country increases the opportunity costs of returning home and therefore the migrants stay abroad longer. The second term is the income effect of a change in the

5 In the cases where $\mathrm{E}\left[\mathrm{w}_{\mathrm{I}}\right]$ equals its expected value or the individuals' utility function is linear or quadratic in consumption, equation (4) reduces to the certainty decision rule $\mathrm{w}_{\mathrm{I}} \mathrm{u}_{\mathrm{H}}^{\prime}-(1-\mathrm{t}) \mathrm{u}_{\mathrm{H}}=0$.

6 See Block and Heineke $(1973,1975)$ for a similar analysis regarding the labor supply decision under uncertainty. 
expected wage rate of the host country and is negative. An increase in the expected wage rate of the host country increases consumption possibilities in the home country and therefore has a negative effect on the optimal migration duration.

Overall, equation (7) implies that the impact of an increase in the expected wage on the optimal migration duration is ambiguous. Since networks are expected to raise the return to migration the ultimate effect of bigger networks on the duration of migration depends on the relative magnitude of the income and substitution effects. We also do not have clear expectations of the duration effects of migrants' human capital characteristics (schooling, age, and labor market experience). For example, if skilled workers are in greater demand than unskilled workers in the host country and therefore can expect a higher wage rate, skilled workers will only stay longer than unskilled workers if the substitution effect in equation (7) exceeds the income effect.

Changes in the amount of uncertainty may be interpreted as shifts in the higher central moments of $\mathrm{f}\left(\mathrm{w}_{\mathrm{I}}\right)$. Following the suggestion of Arrow (1965), we analyze the effects of a pure increase in the dispersion of uncertainty by means of a multiplicative parameter shift followed by an additive shift that leaves the mean unchanged. Thus, we replace $\mathrm{w}_{\mathrm{I}}$ in equation (4) with $\alpha_{2} \mathrm{w}_{\mathrm{I}}+\beta_{2}$. Since we want $\mathrm{E}\left[\mathrm{w}_{\mathrm{I}}\right]$ unchanged, $\mathrm{dE}\left[\alpha_{2} \mathrm{w}_{\mathrm{I}}+\beta_{2}\right]=0$ and $\mathrm{d} \beta_{2} / \mathrm{d} \alpha_{2}=-\mathrm{E}\left[\mathrm{w}_{1}\right]$. Differentiating (4) with respect to $\alpha_{2}$, and evaluating the derivative at $\alpha_{2}=1$ and $\beta_{2}=0$ gives us

$$
\begin{aligned}
\frac{\mathrm{dt}^{*}}{\mathrm{~d} \alpha_{2}} & =-\frac{\mathrm{E}\left[\mathrm{u}_{\mathrm{H}}^{\prime}\right]}{\mathrm{Z}}\left(\mathrm{w}_{\mathrm{I}}-\mathrm{E}\left[\mathrm{w}_{\mathrm{I}}\right]\right)-\frac{\mathrm{t}}{(1-\mathrm{t})^{2}} \frac{\mathrm{E}\left[\mathrm{u}_{\mathrm{H}}^{\prime \prime}\right]}{\mathrm{Z}}\left(\mathrm{w}_{\mathrm{I}}-\mathrm{E}\left[\mathrm{w}_{\mathrm{I}}\right]\right) \\
& =-\frac{\operatorname{cov}\left(\mathrm{w}_{\mathrm{I}}, \mathrm{u}_{\mathrm{H}}^{\prime}\right)}{\mathrm{Z}}-\frac{\mathrm{t}}{(1-\mathrm{t})^{2}} \frac{\operatorname{cov}\left[\mathrm{w}_{\mathrm{I}}, \mathrm{w}_{\mathrm{I}} \mathrm{u}_{\mathrm{H}}^{\prime \prime}\right]}{\mathrm{Z}} .
\end{aligned}
$$

The first term on the right-hand side of equation (8) is the substitution effect and the second term is the income effect of increased uncertainty about the wage rate in the host country. Due to our assumption that migrants are risk-averse, the substitution effect (here, the response of a migrant's time allocation decision due solely to changes in the wage-rate uncertainty) is negative. In other words, if the wage rate abroad becomes more uncertain the migrant will substitute time in the home country for time abroad because he prefers a secure 
consumption flow. From our assumption about the coefficient of absolute risk aversion it can be shown that $\mathrm{u}_{\mathrm{H}}^{\prime \prime}$ is increasing in $\mathrm{w}_{\mathrm{I}}$ and thus $\operatorname{cov}\left(\mathrm{w}_{\mathrm{I}}, \mathrm{u}_{\mathrm{H}}{ }_{\mathrm{H}}^{\prime \prime}\right)$ is positive. ${ }^{7}$ Therefore, the income effect in equation (8) (the response of the time allocation decision attributed solely to the increased consumption uncertainty implied by the increase in the uncertainty about the host countries' wage rate) is positive. Since migration networks typically decrease the level of uncertainty about the wage rate, their effect on the duration of staying abroad is ambiguous.

Beyond human capital characteristics and migration networks, other factors affect the duration of migration. Family size influences the costs of household production while the migrant works abroad. Since a larger family increases the probability that relatives can assume responsibility during the migrants' absence, migration duration should be positively correlated with family size. The wife's employment status and education may further determine how long the migrant stays abroad. If the wife is employed, managing family activities during the husband's absence may be more difficult for her. Furthermore, if the wife's income potential is increasing with her education and if the wife has to leave the labor market when the husband migrates, the opportunity costs of migration increases. If this is so then the duration of migration is negatively related to the education and the employment status of the migrant's wife.

\section{Egyptians' Migration Experience and Description of Sample}

Before 1973, Egypt was an immigration country rather than an emigration country. ${ }^{8}$ Although systematic emigration began in the late 1930's within a program that sponsored the migration of teachers to Iraq and was extended to include other Arab countries after 1952, emigration was controlled through "exit visa" requirements. In the beginning of the 1970s the migration policy liberalized. This change in immigration policy combined with an increased demand for skilled and unskilled labor in oil-rich countries after the world energy crisis in 1973 led to a dramatic increase in emigration from Egypt. The main receiving countries are Saudi Arabia,

7 From the coefficient of absolute risk aversion, $\mathrm{R}=-\mathrm{u}_{\mathrm{H}}^{\prime \prime} / \mathrm{u}_{\mathrm{H}}^{\prime}$, follows that $\mathrm{u}_{\mathrm{H}}^{\prime \prime}=-\mathrm{u}_{\mathrm{H}}^{\prime} \mathrm{R}<0$. Differentiating this expression with respect to $\mathrm{w}_{\mathrm{I}}$ gives us $\frac{\partial \mathrm{u}_{\mathrm{H}}^{\prime \prime}}{\partial \mathrm{w}_{\mathrm{I}}}=-\frac{\mathrm{t}}{\mathrm{t}-1}\left(\mathrm{R}^{\prime} \mathrm{u}_{\mathrm{H}}^{\prime}+\mathrm{Ru}_{\mathrm{H}}^{\prime \prime}\right)>0$, where $\mathrm{R}^{\prime}=\partial \mathrm{R} / \partial \mathrm{c}_{\mathrm{H}}$.

8 See Aly and Shields (1996), Kandil and Metwally (1992), Richards (1994), and Sell (1988) for a description of the Egyptian migration experience and migration policy. 
Kuwait, the United Emirates, Libya, Jordan and Iraq. The literature mentions two reasons why migration to these countries has been mainly temporary. First, most of the receiving countries discourage the permanent residence of migrants. Second, most Egyptian migrants have an intrinsic desire to return home after satisfying their financial or educational objectives (Kandil and Metwally, 1992, Sell, 1988).

The number of Egyptians working in oil-rich countries in 1975 is estimated to lie between 370,000 and 400,000 (see Kandil and Metwally, 1992, and Sell, 1988). In 1985 about $10 \%$ of the Egyptian labor force or between 2.5 to 3.5 million workers were estimated to be working in a foreign country (Sell, 1988). This large-scale emigration had dramatic impacts on several labor markets in Egypt. Aly and Shields (1996) report that between 1970 and 1979 about 10\% of the agricultural workers left Egypt and between 1973 and 1978 the construction sector lost about half of its labor force. Richards (1994) calculates that emigration flows account for roughly two-thirds of the reduction in the agricultural labor force in 1983. Hence, it is not surprising that Egyptian emigration resulted in huge wage increases in the agricultural and construction sector (Aly and Shields, 1996; Richards, 1994).

We use data collected in May and July 1987 and May and July 1988 in six rural villages in three different provinces of Egypt. ${ }^{9}$ The data consists of three different surveys: (i) a household survey which provides information on basic characteristics of the households and information on their migration experience; (ii) a survey of migrants identified in these households of which about $71 \%$ had returned at the time of the survey; and (iii) a survey of randomly selected return migrants that provides detailed information about their migration experience. Unfortunately, the first and second surveys provide only little information on the socioeconomic characteristics of the migrants.

The villages covered by the surveys represent diverse ethnic and geographic distributions. Two of the villages are located in the western delta (Shanawan and Kafr Shanawan), two are in the eastern delta (Tambul el Kubra and Kafr Yussuf), and two are in upper Egypt (Abu Girg and Bani Wallims). The majority of the population in the smallest village, Kafr Yusuf, is Christian, unlike the other locations. All migrants in the sub-sample are male. As shown in Table 1, the villages vary in size and their degree of urbanization and modernization. Table 1 also indicates that the heads of the households with migrants are more

\footnotetext{
9 The data are thoroughly described in Reichert (1993).
} 
educated than the average household head in the villages. Across all six villages the occupational distribution of households with migrants is similar to the overall occupational distribution. Thus, migration is not solely a phenomenon of agricultural families. On average one person from each household migrated.

We use the survey of return migrants in our econometric analysis of migration duration. Table 2 provides descriptive statistics of the variables used in the analysis. Our sample consists of 474 returned male migrants who visited either Iraq, Saudi Arabia, Jordan, or Libya. Migration in our sample begins no earlier than 1957 and ends no later than May 1988. Table 2 and Figure 1 show that $48 \%$ of the migrants stayed less than two years abroad, $24 \%$ stay between two and three years, and $28 \%$ stayed more than three years. These numbers are similar to those of the 1987 CAPMAS Survey, which also addresses duration of stay abroad (Richards, 1994). The 1987 CAPMAS survey found 59\% of rural migrants had been out of Egypt for less than two years, 19\% out of Egypt between two and three years, and 22\% stayed abroad for more than three years.

The variables considered in the empirical analysis can be broadly separated into four groups. The first group includes the educational level of the migrant and his occupation in the host country. These variables control for the earnings potential of the migrants in the host country. Table 2 indicates a tendency of highly educated migrants and those migrants who find employment as skilled workers to stay abroad longer. The second group of variables describes the family situation of the migrant, including family size and dummy-variables indicating whether the migrant is married, the head of the household, and whether his wife works or if she is literate. $92 \%$ of the return migrants are married, though we are not certain of their marital status at the time of migration. Table 2 shows that household heads and those migrants with literate spouses tend to stay abroad longer. For the other variables in this group no clear pattern regarding migration duration emerges.

The third group of variables tries to capture the uncertainty of the migrants about the labor market in the host country. Dummy variables indicating the host country of the migrant control for the political and economic situation in the receiving country. Table 2 shows remarkable differences between the different host countries. Whereas migrants tend to stay only a very short time in Iraq and Jordan, the majority of migrants who stay longer than five years abroad migrate to Saudi Arabia. In addition, we include as a macroeconomic indicator the nominal oil price in the year before the migrant returned. We also consider a dummy 
variable indicating whether the migrant received less income abroad than he expected. Those migrants who expected more income show a slight tendency to stay abroad longer. Finally, we control for network relationships, where the network is defined by the number of fellow villagers who have previously migrated to the same destination country. This variable has been constructed using information from the household survey and the survey of all migrants in the village: we counted the number of migrants from a village who migrated to a particular host country in the time before the year of the first migration of an individual in our sample to the same host country.

Our fourth group of variables reflect the financial arrangements of the migrant. We employ a variable indicating whether the migrant remitted part of his income abroad to his family in Egypt. This variable controls for differences in the migration motives. Table 2 shows that about $64 \%$ of the migrants remitted some of their income during their stay abroad. Furthermore, there is a slight tendency of these migrants to stay abroad longer. This observation is consistent with the theory of migration as a family decision, in which the act of migration is seen as a diversification response in the presence of income risk (see Lucas and Stark, 1985, and Stark, 1980). According to this theory the household spreads its income risks by sending some members to countries where income is not highly correlated with the income of the household in the home country. So, remitting migrants may have different migration motives to those who do not remit, where the former could be expected to stay longer abroad due to their contractual insurance arrangements with the family in the home country. Those migrants who do not remit may be migrating in order to reach some specific income target and return when they reach this target. Finally, we include a variable indicating whether the migrant borrowed the money necessary to finance the migration. Like the remittance variable, borrowing reflects the financial arrangements and obligations of the migrant.

\section{Econometric Model}

Since Lancaster's (1979) seminal paper on the duration of unemployment, duration models have become a widely used econometric tool to analyze event histories. ${ }^{10}$ Although in most applications in economics the duration of an event is measured as a discrete variable, duration

10 See Lancaster (1990), Kalbfleisch and Prentice (1980), and Kiefer (1988) for a survey of duration models. 
models are overwhelmingly based on the assumption that duration is a continuous variable. As Fahrmeir and Knorr-Held (1996) and Han and Hausman (1990) show, the proper application of continuous-time duration models to discrete-time data are limited to special cases and could otherwise lead to biased estimates of the baseline hazard function. Since the endogenous variable in our empirical analysis is discrete in nature, i.e., the number of years spent in a foreign country, we use a flexible parametric proportional hazard model for discrete duration data as proposed by Han and Hausman (1990). This model is flexible parametric in the sense that the baseline hazard is non-parametric while the effect of the covariates takes a particular functional form.

The hazard rate is defined as the failure time at time $\tau$ conditional upon survival to time $\tau$ (see Kiefer, 1988):

$$
\lambda_{\mathrm{i}}(\tau)=\lim _{\Delta \rightarrow 0} \frac{\mathrm{P}\left(\tau<\mathrm{t}_{\mathrm{i}}<(\tau+\Delta) \mid \mathrm{t}_{\mathrm{i}}>\tau\right)}{\Delta}=\lambda_{0} \mathrm{e}^{\mathrm{X}_{\mathrm{i}} \beta}, \mathrm{i}=1,2, \ldots, \mathrm{N},
$$

where $\lambda_{0}$ is the baseline hazard function, $X_{i}$ the vector of covariates and $\beta$ a vector of coefficients to be estimated. Specifying the hazard function in the log form of the integrated hazard function leads to:

$$
\ln \int_{0}^{t_{i}} \lambda_{0}(\tau) d \tau=X_{i} \beta+\epsilon_{i}
$$

where $\epsilon_{\mathrm{i}}$ takes the extreme value form $\mathrm{F}\left(\epsilon_{\mathrm{i}}\right)=\exp \left(-\exp \left(\epsilon_{\mathrm{i}}\right)\right)$.

Defining,

$$
\ln \int_{0}^{t} \lambda_{0}(\tau) d \tau=\kappa_{t}
$$

the probability of failure in period $t$ by individual $i$ becomes 


$$
\mathrm{P}\left[\mathrm{T}_{\mathrm{t}-1}<\mathrm{t}_{\mathrm{i}}<\mathrm{T}_{\mathrm{i}}\right]=\int_{\mathrm{\kappa}_{\mathrm{t}-1}-\mathrm{X}_{\mathrm{i}} \beta}^{\mathrm{K}_{\mathrm{t}}-\mathrm{X}_{\mathrm{i}} \beta} \mathrm{f}(\epsilon) \mathrm{d} \epsilon .
$$

The logs of the integrated baseline hazards, $\kappa_{t}$, are treated as constants in each period and are estimated together with the unknown parameters $\beta$. With the extreme value distribution of $\epsilon_{i}$ and defining $\mathrm{y}_{\mathrm{i}}=\mathrm{t}_{\mathrm{i}}-1$ if $\mathrm{t}_{\mathrm{i}}$ falls in the interval $\mathrm{t}$, the probability in equation (12) is identical to the ordered logit model where the threshold values are interpreted as the logs of the baseline hazard. The estimated hazard rates could be computed at the means of the covariates using:

$$
h(t)=\frac{P\left(t_{j}<t_{i}<t_{j+1}\right)}{P\left(t \geq t_{j}\right)}, \text { for } j=0,1, \ldots, J
$$

We assume the last hazard rate is the same as the penultimate, i.e., we assume that $\mathrm{h}(4<\mathrm{t}<5)=\mathrm{h}(\mathrm{t}>5)$.

A well known feature of the ordered logit model is that the estimated coefficients have no clear-cut interpretation for the event probabilities. Therefore, we calculate the marginal effects of changes in the regressors on the respective probabilities to be in one of the differentiated categories of the ordered logit model. These marginals are given by

$$
\begin{aligned}
& \frac{\partial \operatorname{Pr}\left(Y_{i}=0\right)}{\partial X}=-\left(\frac{e^{\beta^{\prime} X}}{1+e^{\beta^{\prime} X}}\right) \beta, \\
& \frac{\partial \operatorname{Pr}\left(Y_{i}=1\right)}{\partial X}=\left(\frac{e^{\beta^{\prime} X}}{1+e^{\beta^{\prime} X}}-\frac{e^{\kappa_{1}-\beta^{\prime} X}}{1+e^{\kappa_{1}-\beta^{\prime} X}}\right) \beta, \\
& \cdot \\
& \frac{\partial \operatorname{Pr}\left(Y_{i}=J\right)}{\partial X}=\left(\frac{e^{\kappa_{j-1}-\beta^{\prime} X}}{1+e^{\kappa_{j-1}-\beta^{\prime} X}}\right) \beta,
\end{aligned}
$$


for $\mathrm{i}=1,2, \ldots, \mathrm{N}$ and $\mathrm{j}=0,1, \ldots, \mathrm{J}$ (see Greene, 1993). The marginal effects are calculated at the sample means of the covariates. All estimations are performed using the software package LIMDEP 7.0 (see Greene, 1995).

\section{Estimation Results}

The results of maximum likelihood estimations of different specifications of equation (12) are presented in Table 3. For each specification the estimated hazard rates, which have been calculated using equation (13), are reported at the bottom of Table 3. For all specifications considered, the estimated hazard rates generally exhibit positive duration dependence, which means that the probability of returning to Egypt at each point of time is increasing with the time spent abroad. Referring to column (1) of Table 3, the estimated hazard rates show that the probability of returning within the first year is $14.2 \%$. Conditional on staying abroad for at least two years this probability increases to $53.8 \%$ and, conditional on staying abroad at least four years, to $58.7 \%$. Note, however, that the conditional probability to return to Egypt conditional on staying abroad at least for three years is smaller than the return probability conditional on being abroad for at least two years. One possible explanation for this result is that relatively more migrants are forced to return to Egypt after three years of working abroad because their temporary work contract expires.

The estimated coefficients for the covariates show that migration duration is significantly and positively affected by schooling level and occupational status. The schooling level of the migrant's spouse becomes statistically significant and negative when the network variable is added to the specification. None of the other variables describing the family situation of the migrant have a statistically significant impact on migration duration. Migrating to Saudi Arabia or Libya significantly increases the duration of staying abroad compared with migrating to Iraq. Column (2) and Column (3) of Table 3 shows that the migrant's village network and the oil price in the year before the migrant's return have a highly significant negative effect on the duration of staying abroad. Including both the oil price and the network variables (column (4)) in the specification increases the explanatory power of the regression without having significant effects on the other covariates, though the educational level of the migrant's wife becomes negative and statistically significant on a $5 \%$ level. Whether or not the migrant 
borrowed money to cover the costs of migration, or the migrant does not receive the income he expected, has a statistically insignificant effect on migration duration. If the migrant remits some income he earns abroad to his family in Egypt, he stays significantly longer in the host country.

We present in Table 4 the marginal effects of the specification of column (4) from Table 3 , which are calculated at the sample means of the covariates using equation (14). As previously mentioned, the estimated marginal effects of the respective coefficients provide a more clear-cut interpretation of the influence of the covariates on the duration of staying abroad. These marginal effects indicate that the duration of migration increases with the skill level of the migrant. For example, compared with illiterate migrants, the probability of staying less than one year abroad is $5 \%$ smaller for literate migrants and $12 \%$ smaller for migrants with a university degree. Similar to the results regarding formal education, skilled workers stay abroad longer than their unskilled counterparts. Assuming that a higher skill level and a higher occupational status abroad increase the earnings potential of migrant, these results indicate that the substitution effect of a higher expected wage rate abroad is larger than the income effect (see equation (7) in section 2).

Consistent with our expectations that a higher income potential for the migrants' wife increases the opportunity costs of staying abroad, migration duration significantly decreases when the wife of the migrant is literate. Compared with those migrants with illiterate wives, the probability of a migrant with a literate wife staying abroad for less than one year is $6.4 \%$ higher and the probability of staying more than five years abroad is $2.4 \%$ smaller.

Turning to the variables describing the situation in the host countries it appears that the migrants stay significantly longer in Libya and, in particular, Saudi Arabia, compared with those migrants moving to Iraq or Jordan. The higher the oil price the shorter the duration of the migrant's stay. Interpreting the oil price as an indicator for the economic situation in the destination region, this result is consistent with the hypotheses that a higher oil price increases the wages of the migrants, who can then reach their migration goals in a shorter time.

The extent of the social network of the migrant in the respective receiving country decreases the length of staying abroad. This effect is illustrated in Figure 2, holding all other covariates at their sample means. The figure clearly shows that the first migrants to a particular country have a higher probability of staying there for a longer time. However, the probability of staying in the receiving country for less than one year sharply increases with the 
number of individuals from a village who have previously migrated to a particular country. For example, if we compare the situation where no informational networks exist to a situation where 50 people from a village have previously migrated to a particular host country, the probability that a current migrant stays in the country for less than one year increases from $12 \%$ to $92 \%$. These results indicate, again, that the substitution effect of lower uncertainty about the wage abroad dominates the income effect (see equation (8) in section 2).

Finally we find that if the migrant remits some of his income in the destination country to his family back home in Egypt the probability of staying less than one year abroad decreases by $14 \%$ and the probability to stay between one and two years decreases by $18 \%$. This is consistent with the view that the underlying motives of migrants who remit are different from the motives of migrants who fail to remit, where the latter seem to migrate to achieve a specific target. The behavior of remitting migrants can be interpreted as the result of a contractual arrangement among family members that seeks to reduce household income risk.

\section{Summary}

In the 1970s and 1980s Egypt experienced large-scale emigration to oil-rich countries that resulted in labor shortages and subsequent wage increases in specific Egyptian labor markets. A remarkable attribute of Egyptian emigration is its temporary nature. According to representative surveys, 59\% of rural Egyptian migrants return within two years and $78 \%$ within three years. This paper analyzes the determinants and timing of return migration where special attention is given to the role of social and informational migration networks. In an uncertain environment, these networks provide potential migrants with information about the labor market in the host country and therefore increase the expected wage rate and decrease the variability of the wages abroad by increasing the probability of obtaining a better paid and more stable job.

A simple theoretical model demonstrates that the effect of migration networks on the optimal migration duration is ambiguous. An increased expected wage rate in the host country leads only to a longer stay abroad if the increased opportunity costs of returning to the home country exceed the increased consumption possibilities at home. Similarly, there exist two opposing effects of decreased wage variability in the host country on the optimal migration duration. On the one hand, if the wage rate abroad becomes less uncertain the migrant substitutes time in the home country for time in the host country. On the other hand, 
decreased consumption uncertainty implied by the decrease in the uncertainty about the host countries' wage leads to a shorter stay abroad.

Using a sample of return migrants from six different villages in Egypt we investigate the determinants of migration duration. The estimations were performed using a flexible parametric proportional hazard model for discrete duration data. The estimation results imply that migration duration is positively related to the skill level and the occupational status of the migrant. Consistent with theoretical models that consider the migration act to be a household decision rather than an individual decision, migrants who remit some of their income to their families in Egypt stay abroad longer. If the migrant's wife is literate, his stay abroad is shorter. Egyptian migrants stay significantly longer in Saudi Arabia and Libya than in Iraq and Jordan. The oil-price in the year before a migrant's return, which we interpret as an indicator of the income possibilities in the host country, is negatively related to migration duration. Whether or not the migrant is a household head, the migrant's wife participates in the labor force, he borrowed money to cover the migration costs, or does not receive the income he expected, have no significant impact on migration duration.

Controlling for human capital and demographic characteristics of the migrant and economic indicators for the host countries, the empirical results show a statistically significant negative effect of informational networks on migration duration. The estimations imply that if we compare the situation where no informational networks exist to a situation where 50 people from a village have previously migrated to a particular host country, the probability that a current migrant stays in the country for less than one year increases from $12 \%$ to $92 \%$. 


\section{References}

Aly, Hassan Y., and Michael P. Shields (1996): “A Model of Temporary Migration: The Egyptian Case," International Migration, 34(3), 431-445.

Banerjee, Biswajit (1983): "Social Networks in the Migration process: Empirical Evidence on Chain Migration in India," Journal of Developing Areas, 17, 185-196.

Bauer, Thomas (1995). "The Migration Decision with Uncertain Costs," University of Munich Discussion Paper \#95-25.

Bauer, Thomas and Klaus F. Zimmermann (1997). "Network Migration of Ethnic Germans," International Migration Review 31, 143-149.

Block, M.K., and J.M. Heineke (1973): "The Allocation of Effort under Uncertainty: The Case of Risk-averse Behavior," Journal of Political Economy, 81(2), 376-385.

Block, M.K., and J.M. Heineke (1975): "Factor Allocations under Uncertainty: An Extension," Southern Economic Journal, 41(3), 526-530.

Boyd, M. (1989): "Family and Personal Networks in International Migration: Recent Developments and New Agendas," International Migration Review, 23, 638-670.

Co, Catherine Yap, Ira N. Gang, and Yun Myeong-Su (1998). "Returns to Returning: Who Went Abroad and What Does It Matter?", manuscript.

Djajic, S., and R. Milbourne (1988): “A General Equilibrium Model of Guest Worker Migration," Journal of International Economics 25, 335-351.

Dustmann, Christian (1995): "Savings Behavior of Migrant Workers: A Life-Cycle Analysis," Zeitschrift für Wirtschafts- und Sozialwissenschaften, 115, 511-33.

Dustmann, Christian (1997). "Return Migration, Uncertainty and Precautionary Savings," Journal of Development Economics 52, 295-316.

Fahrmeir, Ludwig, and Leonhard Knorr-Held (1996): "Dynamic Discrete-Time Duration Models," SFB-386 Discussion Paper 14, University of Munich.

Greene, William H. (1993): Econometric Analysis. Second Edition. Macmillan: New York.

Greene, William H. (1995): LIMDEP, Version 7.0 User's Manual. Econometric Software: Plainview, NY.

Han, Aaron, and Jerry A. Hausman (1990): "Flexible Parametric Estimation of Duration and Competing Risk Models," Journal of Applied Econometrics, 5, 1-28.

Hill, John K. (1987). "Immigrant Decisions Concerning Duration of Stay and Migratory Frequency," Journal of Development Economics 25, 221-234.

Kalbfleisch, J.D., and R. L. Prentice (1980): The Statistical analysis of Failure Time Data. New York: John Wiley \& Sons.

Kandil, M., and M. Metwally (1992): "Determinants of the Egyptian Labour Migration," International Migration, 30(1), 39-55.

Kiefer, N. (1988): "Economic Duration Data and Hazard Functions," Journal of Economic Literature, 26, 646-679.

Lancaster, T. (1979): "Econometric Methods for the Duration of Unemployment," Econometrica, 47, 939-956.

Lancaster, T. (1990): The Econometric Analysis of Transition Data. Cambridge: Cambridge University Press.

Lucas, R. E. B., and O. Stark (1985): "Motivations to Remit: Evidence from Botswana," Journal of Political Economy, 93(5), 901-918.

Massey, D.S. (1990): "Social Structure, household Strategies, and the Cummulative Causation of Migration," Population Index, 56, 3-26. 
Massey, D.S., J. Arango, G. Hugo, A. Kouaouci, A. Pellegrino, and J.E. Taylor (1993): "Theories of International Migration: A Review and Appraisal," Population and Development Review, 19, 431-466.

Reichert, Christoph (1993). "Labour Migration and Rural Development in Egypt," Sociologia Ruralis 33, 42-60.

Richards, Alan (1994). "The Egyptian Farm Labor Market Revisited," Journal of Development Economics 43, 239-261.

Sell, Ralph R. (1988): "Egyptian International Labor Migration and Social Processes: Toward Regional Integration," International Migration Review, 22(3), 87-108.

Stark, Oded (1980): "On the Role of Urban-to-Rural Remittances in Rural Development," Journal of Development Studies, 16(3), 369-374.

Stark, Oded (1991). The Migration of Labor. Cambridge, Massachusetts: Basil Blackwell.

Stark, Oded (1995): "Return and Dynamics: The Path of Labor Migration when Workers Differ in their Skills and Information is Asymmetric," Scandinavian Journal of Economics, 97(1), 55-71.

Stark, Oded, Christian Helmenstein and Yury Yegorov (1997). "Migrants' Savings, Purchasing Power Parity, and the Optimal Duration of Migration," International Tax and Public Finance 4, 307-324. 
Table 1: Basic Village and Migration Data*

\begin{tabular}{|c|c|c|c|c|c|c|}
\hline & Shanawan & Kafr Shanawan & Abu Girg & Bani Wallims & Tambul el Kubra & Kafr Yussuf \\
\hline Village Population & 23,250 & 4,315 & 15,477 & 6,881 & 7,245 & 1,417 \\
\hline Red Brick Houses (\%) & 85.4 & 82.9 & 41.5 & 65.7 & 33.6 & 16.6 \\
\hline Illiteracy Rate of Household Heads (\%) & 68.7 & 73.1 & 85.9 & 92.6 & 82.7 & 76.2 \\
\hline Agricultural Occupations (\%) & 18.3 & 22.8 & 58.7 & 64.3 & 54.6 & 65.0 \\
\hline Households with Migrants (\%) & 18.5 & 21.4 & 42.2 & 29.2 & 32.1 & 43.2 \\
\hline \multicolumn{7}{|l|}{ Among Households with Migrants: } \\
\hline Illiteracy Rate of Household Heads (\%) & 22.2 & 31.7 & 57.9 & 70.3 & 53.0 & 88.0 \\
\hline $\begin{array}{l}\text { Agricultural Occupation of Household } \\
\text { Head }(\%)\end{array}$ & 12.8 & 27.6 & 56.3 & 63.7 & 57.1 & 76.7 \\
\hline Household Members & $\begin{array}{c}5.37 \\
(2.30)\end{array}$ & $\begin{array}{c}6.06 \\
(3.12)\end{array}$ & $\begin{array}{c}6.67 \\
(3.57)\end{array}$ & $\begin{array}{c}6.00 \\
(2.66)\end{array}$ & $\begin{array}{c}5.19 \\
(1.98)\end{array}$ & $\begin{array}{c}7.22 \\
(3.39)\end{array}$ \\
\hline Number of Migrants in Household & $\begin{array}{c}1.06 \\
(0.24)\end{array}$ & $\begin{array}{c}1.21 \\
(0.46)\end{array}$ & $\begin{array}{c}1.21 \\
(0.59)\end{array}$ & $\begin{array}{c}1.15 \\
(0.45)\end{array}$ & $\begin{array}{c}1.02 \\
(0.13)\end{array}$ & $\begin{array}{c}1.20 \\
(0.50)\end{array}$ \\
\hline
\end{tabular}

* Source: Village Household Survey, Household sub-sample ( $\mathrm{N}=8,620$ households, $\mathrm{N}=2,483$ migrants in households) and Reichert (1993). Standard deviations in parentheses. 
Table 2: Descriptive Statistics by Migration Duration*

\begin{tabular}{|c|c|c|c|c|c|c|c|c|}
\hline & & \multirow[b]{2}{*}{ Total } & \multicolumn{6}{|c|}{ 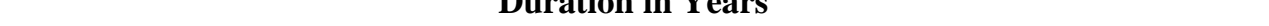 } \\
\hline & & & Less than 1 & $\begin{array}{c}\text { Between } \\
1 \text { and } 2\end{array}$ & $\begin{array}{l}\text { Between } \\
2 \text { and } 3\end{array}$ & $\begin{array}{c}\text { Between } \\
3 \text { and } 4\end{array}$ & $\begin{array}{c}\text { Between } \\
4 \text { and } 5\end{array}$ & More than 5 \\
\hline \multirow[t]{6}{*}{ Village (\%): } & Shanawan & 30.4 & 14.6 & 37.1 & 28.6 & 25.0 & 51.2 & 31.6 \\
\hline & Kafr Shanawan & 4.9 & 4.5 & 2.1 & 2.7 & 7.7 & 11.6 & 10.5 \\
\hline & Abu Girg & 19.0 & 12.4 & 8.6 & 17.9 & 30.8 & 27.9 & 50.0 \\
\hline & Bani Wallims & 16.3 & 12.4 & 17.9 & 26.8 & 13.5 & 7.0 & 0.0 \\
\hline & Tambul el Kubra & 16.7 & 19.1 & 22.9 & 17.0 & 15.4 & 2.3 & 5.3 \\
\hline & Kafr Yussuf & 13.1 & 37.1 & 11.4 & 7.1 & 7.7 & 0.0 & 2.6 \\
\hline \multirow[t]{3}{*}{ Education (\%): } & Illiterate & 40.7 & 52.8 & 42.1 & 42.0 & 34.6 & 18.6 & 36.8 \\
\hline & Literate & 28.5 & 21.4 & 32.1 & 25.0 & 28.9 & 32.6 & 36.8 \\
\hline & University Degree & 31.1 & 25.8 & 26.4 & 33.0 & 36.5 & 48.8 & 26.3 \\
\hline \multirow[t]{3}{*}{ Occupation Abroad (\%): } & Unskilled Worker & 70.7 & 83.2 & 75.0 & 72.3 & 65.4 & 51.2 & 50.0 \\
\hline & Skilled Worker & 21.9 & 10.1 & 17.7 & 17.9 & 26.9 & 44.2 & 44.7 \\
\hline & Other & 6.3 & 6.7 & 5.7 & 7.1 & 7.7 & 4.7 & 5.3 \\
\hline \multicolumn{2}{|l|}{ Married (in \%) } & 91.6 & 95.5 & 87.1 & 88.4 & 94.2 & 97.7 & 97.4 \\
\hline \multicolumn{2}{|l|}{ Household Head (in \%) } & 82.5 & 79.8 & 80.7 & 83.0 & 76.9 & 93.0 & 89.5 \\
\hline \multicolumn{2}{|l|}{ Wife Works (in \%) } & 24.1 & 21.4 & 19.3 & 35.7 & 21.2 & 20.9 & 21.1 \\
\hline \multicolumn{2}{|l|}{ Wife Literate (in \%) } & 37.1 & 27.0 & 36.4 & 42.0 & 40.4 & 46.5 & 34.2 \\
\hline \multirow{2}{*}{\multicolumn{2}{|c|}{ Family Members }} & 5.50 & 6.06 & 5.32 & 5.34 & 5.48 & 4.84 & 6.05 \\
\hline & & $(2.17)$ & $(2.23)$ & $(2.24)$ & $(2.03)$ & $(2.24)$ & $(1.90)$ & $(2.13)$ \\
\hline \multirow[t]{4}{*}{ Host countries (\%): } & Iraq & 59.3 & 74.2 & 70.7 & 64.3 & 44.2 & 23.3 & 29.0 \\
\hline & Saudi Arabia & 29.5 & 15.7 & 20.0 & 26.8 & 38.5 & 58.1 & 60.5 \\
\hline & Jordan & 4.2 & 6.7 & 4.3 & 2.7 & 5.8 & 4.7 & 0.0 \\
\hline & Libya & 5.9 & 2.3 & 5.0 & 6.3 & 7.7 & 9.3 & 10.5 \\
\hline \multirow{2}{*}{\multicolumn{2}{|c|}{ Oil price (in Egypt $£$ ) }} & 56.54 & 62.38 & 55.60 & 56.47 & 58.27 & 55.67 & 45.29 \\
\hline & & $(28.71)$ & $(27.29)$ & $(30.20)$ & $(26.08)$ & $(27.68)$ & $(30.81)$ & $(30.69)$ \\
\hline \multirow{2}{*}{\multicolumn{2}{|c|}{ Network }} & 84.92 & 97.83 & 98.24 & 83.05 & 68.48 & 68.30 & 52.45 \\
\hline & & $(86.20)$ & (95.63) & (105.3) & $(86.40)$ & $(82.71)$ & (79.92) & $(65.59)$ \\
\hline \multicolumn{2}{|l|}{ Borrowed (in\%) } & 53.8 & 42.7 & 63.6 & 50.0 & 50.0 & 55.8 & 57.9 \\
\hline \multicolumn{2}{|l|}{ Remittances (in \%) } & 63.7 & 32.6 & 55.0 & 78.6 & 80.8 & 76.7 & 86.8 \\
\hline \multicolumn{2}{|c|}{ Expected more Income (in \%) } & 11.0 & 5.6 & 10.0 & 12.5 & 19.2 & 11.6 & 10.5 \\
\hline \multicolumn{2}{|c|}{ Duration } & $\begin{array}{c}1.97 \\
(1.84)\end{array}$ & - & - & - & - & - & - \\
\hline \multicolumn{2}{|l|}{ Observations } & 474 & 89 & 140 & 112 & 52 & 43 & 38 \\
\hline
\end{tabular}


Table 3:

Estimation Results from Ordered Logit Model (Dependent Variable: Years Spend Abroad)

\begin{tabular}{|c|c|c|c|c|}
\hline Variables & (1) & (2) & (3) & (4) \\
\hline Literate & $\begin{array}{c}0.426^{\dagger} \\
(0.226)\end{array}$ & $\begin{array}{c}0.368^{\dagger} \\
(0.223)\end{array}$ & $\begin{array}{l}0.489^{\dagger \dagger} \\
(0.226)\end{array}$ & $\begin{array}{l}0.465^{\dagger \dagger} \\
(0.221)\end{array}$ \\
\hline University Degree & $\begin{array}{l}1.039^{\dagger \dagger} \\
(0.316)\end{array}$ & $\begin{array}{l}1.037^{\dagger \dagger} \\
(0.318)\end{array}$ & $\begin{array}{l}1.077^{\dagger \dagger} \\
(0.318)\end{array}$ & $\begin{array}{l}1.125^{\dagger \dagger} \\
(0.328)\end{array}$ \\
\hline Skilled Worker & $\begin{array}{l}0.741^{\dagger \dagger} \\
(0.233)\end{array}$ & $\begin{array}{l}0.649^{\dagger \dagger} \\
(0.237)\end{array}$ & $\begin{array}{l}0.804^{\dagger} \\
(0.231)\end{array}$ & $\begin{array}{l}0.695^{\dagger \dagger} \\
(0.237)\end{array}$ \\
\hline Other Occupation & $\begin{array}{c}0.183 \\
(0.382)\end{array}$ & $\begin{array}{l}-0.011 \\
(0.397)\end{array}$ & $\begin{array}{c}0.168 \\
(0.381)\end{array}$ & $\begin{array}{c}-0.198 \\
(0.386)\end{array}$ \\
\hline Married & $\begin{array}{c}0.245 \\
(0.452)\end{array}$ & $\begin{array}{l}-0.022 \\
(0.464)\end{array}$ & $\begin{array}{c}0.381 \\
(0.454)\end{array}$ & $\begin{array}{c}0.078 \\
(0.480)\end{array}$ \\
\hline Household Head & $\begin{array}{l}-0.014 \\
(0.294)\end{array}$ & $\begin{array}{l}-0.209 \\
(0.305)\end{array}$ & $\begin{array}{c}0.025 \\
(0.298)\end{array}$ & $\begin{array}{c}-0.024 \\
(0.318)\end{array}$ \\
\hline Wife Works & $\begin{array}{c}0.115 \\
(0.147)\end{array}$ & $\begin{array}{c}0.085 \\
(0.136)\end{array}$ & $\begin{array}{c}0.106 \\
(0.151)\end{array}$ & $\begin{array}{c}0.045 \\
(0.136)\end{array}$ \\
\hline Wife Literate & $\begin{array}{l}-0.280 \\
(0.271)\end{array}$ & $\begin{array}{l}-0.490^{\dagger} \\
(0.275)\end{array}$ & $\begin{array}{l}-0.255 \\
(0.271)\end{array}$ & $\begin{array}{c}-0.595^{\dagger \dagger} \\
(0.280)\end{array}$ \\
\hline Family Members & $\begin{array}{l}-0.035 \\
(0.045)\end{array}$ & $\begin{array}{l}-0.078^{\dagger} \\
(0.047)\end{array}$ & $\begin{array}{l}-0.024 \\
(0.046)\end{array}$ & $\begin{array}{c}-0.083 \\
(0.048)\end{array}$ \\
\hline Saudi Arabia & $\begin{array}{l}1.111^{\dagger \dagger} \\
(0.207)\end{array}$ & $\begin{array}{l}1.392^{\dagger \dagger} \\
(0.220)\end{array}$ & $\begin{array}{l}1.131^{\dagger \dagger} \\
(0.209)\end{array}$ & $\begin{array}{l}1.692^{\dagger \dagger} \\
(0.229)\end{array}$ \\
\hline Jordan & $\begin{array}{l}-0.127 \\
(0.429)\end{array}$ & $\begin{array}{l}-0.506 \\
(0.436)\end{array}$ & $\begin{array}{l}-0.175 \\
(0.431)\end{array}$ & $\begin{array}{c}-0.926^{\dagger \dagger} \\
(0.441)\end{array}$ \\
\hline Libya & $\begin{array}{l}0.862^{\dagger \dagger} \\
(0.359)\end{array}$ & $\begin{array}{c}0.634^{\dagger} \\
(0.363)\end{array}$ & $\begin{array}{l}0.767^{\dagger \dagger} \\
(0.349)\end{array}$ & $\begin{array}{c}0.263 \\
(0.348)\end{array}$ \\
\hline Oil price $* 10^{-1}$ & - & - & $\begin{array}{c}-0.098^{\dagger \dagger} \\
(0.030)\end{array}$ & $\begin{array}{c}-0.227^{\dagger \dagger} \\
(0.032)\end{array}$ \\
\hline Network $* 10^{-1}$ & - & $\begin{array}{c}-0.054^{\dagger \dagger} \\
(0.011)\end{array}$ & - & $\begin{array}{c}-0.095^{\dagger \dagger} \\
(0.012)\end{array}$ \\
\hline Borrowed & $\begin{array}{c}0.128 \\
(0.175)\end{array}$ & $\begin{array}{c}0.084 \\
(0.175)\end{array}$ & $\begin{array}{c}0.158 \\
(0.175)\end{array}$ & $\begin{array}{c}0.126 \\
(0.177)\end{array}$ \\
\hline Remittances & $\begin{array}{l}1.266^{\dagger \dagger} \\
(0.198)\end{array}$ & $\begin{array}{l}1.304^{\dagger \dagger} \\
(0.200)\end{array}$ & $\begin{array}{l}1.249^{\dagger \dagger} \\
(0.199)\end{array}$ & $\begin{array}{l}1.295^{\dagger \dagger} \\
(0.204)\end{array}$ \\
\hline Expected more Income & $\begin{array}{c}0.258 \\
(0.298)\end{array}$ & $\begin{array}{c}0.152 \\
(0.303)\end{array}$ & $\begin{array}{c}0.326 \\
(0.298)\end{array}$ & $\begin{array}{c}0.239 \\
(0.303)\end{array}$ \\
\hline Constant & $\begin{array}{l}-0.039 \\
(0.588)\end{array}$ & $\begin{array}{l}1.217^{\dagger} \\
(0.655)\end{array}$ & $\begin{array}{c}0.253 \\
(0.591)\end{array}$ & $\begin{array}{l}2.848^{\dagger \dagger} \\
(0.690)\end{array}$ \\
\hline$\mu_{1}$ & $\begin{array}{l}1.701^{\dagger \dagger} \\
(0.134)\end{array}$ & $\begin{array}{l}1.748^{\dagger \dagger} \\
(0.140)\end{array}$ & $\begin{array}{l}1.716^{\dagger \dagger} \\
(0.135)\end{array}$ & $\begin{array}{l}1.817^{\dagger \dagger} \\
(0.146)\end{array}$ \\
\hline$\mu_{2}$ & $\begin{array}{l}2.941^{\dagger \dagger} \\
(0.166)\end{array}$ & $\begin{array}{l}3.031^{\dagger \dagger} \\
(0.176)\end{array}$ & $\begin{array}{l}2.964^{\dagger \dagger} \\
(0.168)\end{array}$ & $\begin{array}{l}3.167^{\dagger \dagger} \\
(0.184)\end{array}$ \\
\hline$\mu_{3}$ & $\begin{array}{l}3.705^{\dagger \dagger} \\
(0.190)\end{array}$ & $\begin{array}{l}3.822^{\dagger \dagger} \\
(0.200)\end{array}$ & $\begin{array}{l}3.739^{\dagger \dagger} \\
(0.194)\end{array}$ & $\begin{array}{l}4.011^{\dagger \dagger} \\
(0.211)\end{array}$ \\
\hline$\mu_{4}$ & $\begin{array}{l}4.674^{\dagger \dagger} \\
(0.228)\end{array}$ & $\begin{array}{l}4.815^{\dagger \dagger} \\
(0.239)\end{array}$ & $\begin{array}{l}4.728^{\dagger \dagger} \\
(0.235)\end{array}$ & $\begin{array}{l}5.089^{\dagger \dagger} \\
(0.255)\end{array}$ \\
\hline $\mathrm{h}(\mathrm{t}<1)$ & 0.142 & 0.134 & 0.139 & 0.123 \\
\hline $\mathrm{h}(1<\mathrm{t}<2)$ & 0.388 & 0.388 & 0.389 & 0.385 \\
\hline $\mathrm{h}(2<\mathrm{t}<3)$ & 0.538 & 0.551 & 0.540 & 0.568 \\
\hline $\mathrm{h}(3<\mathrm{t}<4)$ & 0.465 & 0.479 & 0.470 & 0.504 \\
\hline $\mathrm{h}(4<\mathrm{t}<5)$ & 0.587 & 0.598 & 0.596 & 0.632 \\
\hline Log-Likelihood & -72578 & -71423 & -72068 & -69366 \\
\hline$\chi^{2}$ & 13883 & 16194 & 14903 & 20307 \\
\hline
\end{tabular}

Standard errors in parentheses. Number of Observations: $474 .{ }^{\dagger}:$ statistically significant at least at the $10 \%$ -

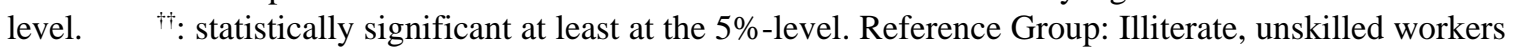
going to Iraq, not married, not household head, wife does work, wife illiterate, did not borrow to go abroad, did not remit, expected less or the same income as received. 
Table 4: Estimated Marginal Effects

\section{Duration in years}

\begin{tabular}{lcccccc} 
Variables & $\begin{array}{c}\text { Less } \\
\text { than 1 }\end{array}$ & $\begin{array}{c}\text { Between } \\
1 \text { and 2 }\end{array}$ & $\begin{array}{c}\text { Between } \\
2 \text { and 3 }\end{array}$ & $\begin{array}{c}\text { Between } \\
3 \text { and 4 }\end{array}$ & $\begin{array}{c}\text { Between } \\
4 \text { and 5 }\end{array}$ & $\begin{array}{c}\text { More } \\
\text { than 5 }\end{array}$ \\
\hline Literate & -0.050 & -0.066 & 0.032 & 0.036 & 0.029 & 0.019 \\
University Degree & -0.120 & -0.159 & 0.078 & 0.086 & 0.069 & 0.046 \\
Skilled Worker & -0.074 & -0.098 & 0.048 & 0.053 & 0.043 & 0.028 \\
Other Occupation & 0.021 & 0.028 & -0.014 & -0.015 & -0.012 & -0.008 \\
Married & -0.008 & -0.011 & 0.006 & 0.006 & 0.005 & 0.003 \\
Household Head & 0.026 & 0.034 & -0.017 & -0.019 & -0.015 & -0.010 \\
Wife Works & -0.005 & -0.006 & 0.003 & 0.003 & 0.003 & 0.002 \\
Wife Literate & 0.064 & 0.084 & -0.042 & -0.046 & -0.037 & -0.024 \\
Family Members & 0.009 & 0.012 & -0.006 & -0.006 & -0.005 & -0.003 \\
Saudi Arabia & -0.181 & -0.239 & 0.118 & 0.130 & 0.104 & 0.069 \\
Jordan & 0.099 & 0.131 & -0.065 & -0.071 & -0.057 & -0.038 \\
Libya & -0.028 & -0.037 & 0.018 & 0.020 & 0.016 & 0.011 \\
Oil price & 0.024 & 0.032 & -0.016 & -0.017 & -0.014 & -0.009 \\
Network & 0.010 & 0.013 & -0.007 & -0.007 & -0.006 & -0.004 \\
Borrowed & -0.014 & -0.018 & 0.009 & 0.010 & 0.009 & 0.005 \\
Remittances & -0.139 & -0.183 & 0.090 & 0.099 & 0.080 & 0.053 \\
Expected more Income & -0.026 & -0.034 & 0.017 & 0.018 & 0.015 & 0.010 \\
Constant & -0.305 & -0.403 & 0.199 & 0.218 & 0.175 & 0.116 \\
\hline Using equan & & & & & &
\end{tabular}

Using equation (14), the marginal effects are calculated at the sample means of the covariates using the estimated coefficients of column (4) from Table 3. 
Figure 1: Years spent abroad

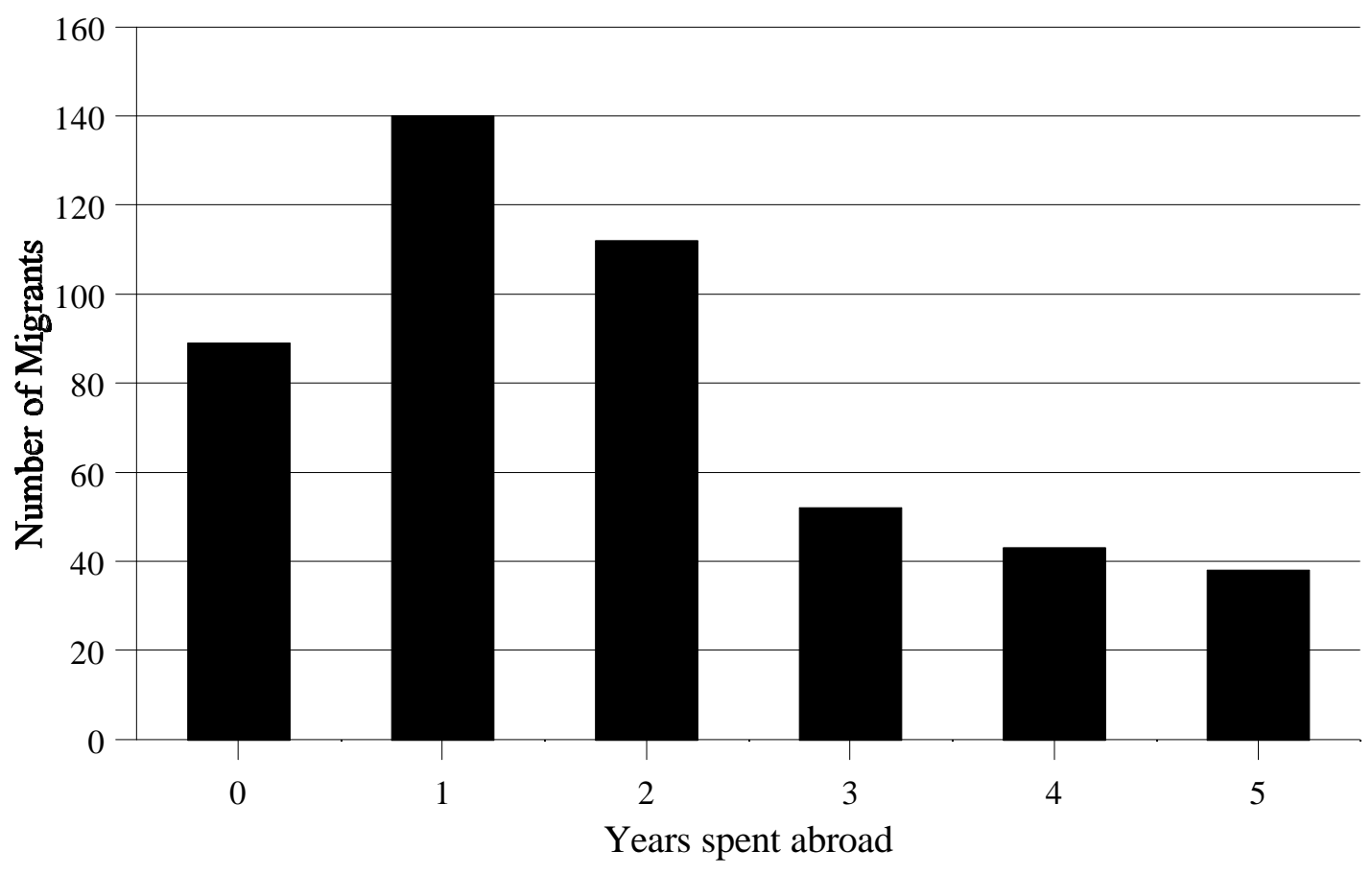

Source: Village Household Survey, Migrant sub-sample ( $N=474$ return migrants for whom we have individual data). 
Figure 2: Social Networks and Migration Duration

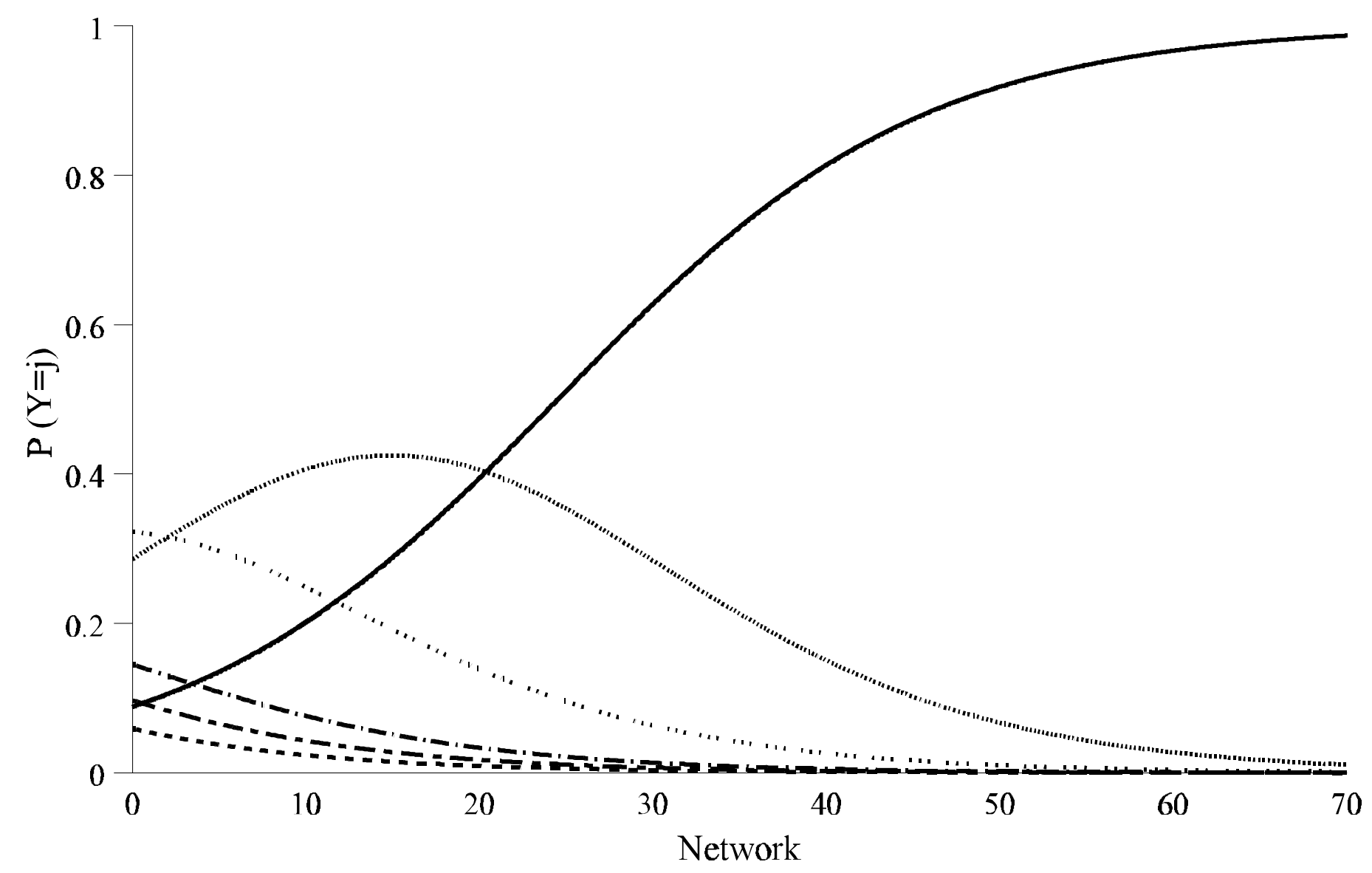

$$
\begin{aligned}
& \begin{array}{llllll}
\mathrm{P}(\mathrm{Y}<1) \quad \cdots \cdots \cdots \cdots \cdots \cdots \cdots & \mathrm{P}(1<\mathrm{Y}<2) & \cdots & \cdots & \cdots & \mathrm{P}(2<\mathrm{Y}<3)
\end{array} \\
& \text {-. - - } \mathrm{P}(3<\mathrm{Y}<4) \quad \text { - - - } \quad \mathrm{P}(4<\mathrm{Y}<5) \quad-\cdots \cdot \mathrm{P}(\mathrm{Y}>5)
\end{aligned}
$$

